\title{
Larvicidal and Repellent Activity of Mentha arvensis L. Essential Oil against Aedes aegypti
}

\author{
Ho Dung Manh ${ }^{1, * \mathbb{D}}$ and Ong Thi Tuyet ${ }^{2}$ \\ 1 Department of Pharmaceutical Chemistry, Faculty of Pharmacy, Lac Hong University, Dong Nai 810000, \\ Vietnam \\ 2 Department of Traditional Medicine, Faculty of Pharmacy, Lac Hong University, Dong Nai 810000, Vietnam; \\ tuyetong2610@gmail.com \\ * Correspondence: manhho@lhu.edu.vn
}

Received: 5 March 2020; Accepted: 21 March 2020; Published: 22 March 2020

\begin{abstract}
Dengue is one of the most dangerous vector-borne diseases transmitted by Aedes mosquitoes. The use of mosquito repellents to protect human hosts and insecticides to reduce the mosquito population is a crucial strategy to prevent the disease. Here, we reported larvicidal and repellent activities of Mentha arvensis L. essential oil against Aedes aegypti, the main vector of the disease. The essential oil was extracted by hydro-distillation from the aromatic plant grown in Vietnam. The yield was $0.67 \%$ based on the weight of fresh leaves. The essential oil was analyzed by gas chromatography-mass spectrometry (GC-MS). The main components were menthol (66.04\%), menthyl acetate $(22.19 \%)$, menthone $(2.51 \%)$, and limonene $(2.04 \%)$. Toxicity test on Aedes aegypti larvae showed that the median lethal concentrations, $\mathrm{LC}_{50}$ and $\mathrm{LC}_{90}$ were $78.1 \mathrm{ppm}$ (part per million) and $125.7 \mathrm{ppm}$, respectively. Besides, the essential oil showed excellent repellency on Aedes aegypti mosquitoes. At $25 \%, 50 \%$, and $100 \%$ concentration, the respective complete protection times (CPTs) were $45 \mathrm{~min}, 90 \mathrm{~min}$, and $165 \mathrm{~min}$. When adding $5 \%$ vanillin to the essential oil $(25 \%)$, the complete protection time of the essential oil increased up to $120 \mathrm{~min}$. In conclusion, the EO from Mentha arvensis L. has been shown to be a promising natural larvicide and repellent against Aedes aegypti mosquitoes.
\end{abstract}

Keywords: Mentha arvensis; essential oil; Aedes aegypti; Larvicidal activity; mosquito repellent

\section{Introduction}

Dengue is one of the most important vector-borne diseases and is transmitted by Aedes mosquitoes. There are millions of infections that occur every year in the world [1,2]. Global warming and human population growth have led to an increase in mosquito population and number of infections [3]. Disease control in practice usually includes using insecticide to reduce the mosquito population [4] and using chemical repellents to protect the human host from mosquito bites [5].

Although synthetic insecticides such as organophosphate, pyrethroid, etc. have reduced the Aedes mosquito population successfully, the continuous increase in the use of the synthetic insecticides has led to mosquito resistance [6], and more importantly, potential toxicity in the environment and adverse effects on human health [7,8]. Besides, repellents are often used to protect against mosquito bites by applying on human skin. One of the most effective chemical repellents is DEET (N,N-diethyl-3-methylbenzamide), which is widely used in commercial products [9]. However, DEET has some potential risks for human health, especially a high level of DEET was reported to have adverse effects on children [10].

Many recent studies have been focused on plant-based products that present low toxicity and reduce the accumulation of toxic chemicals in the environment [11,12]. Among these natural products, essential oils have been shown to be potential alternatives to synthetic chemicals because they are 
effective, eco-friendly and available to many parts in the world affected by mosquito vector-borne disease [13]. For example, common ingredients used in mosquito repellents are citronella oil, lemongrass oil, and para-menthane 3,8-diol (PMD) [14] found in waste distillate after extraction of the eucalyptus citriodora oil.

In this study, we aim to extract the essential oil from the Mentha arvensis L. aromatic plant, grown in southern Vietnam, and to evaluate the larvicidal and repellent activities of the essential oil against Aedes aegypti mosquitoes.

\section{Materials and Methods}

\subsection{Essential oil Extraction}

Mentha arvensis L. plant was collected in Ho Chi Minh city, in July 2018. The plant was identified by a botanist, and a voucher specimen (1903) was deposited at the Faculty of Pharmacy, Lac Hong University, Vietnam. Two hundred grams of the fresh plant leaves were hydro-distilled by using a Clevenger apparatus. The oil layer was separated, and subsequently dried over anhydrous $\mathrm{Na}_{2} \mathrm{SO}_{4}$. Finally, the essential oil was stored in a sealed glass vial and further analyzed using GC-MS.

\subsection{GC/MS}

The essential oil was characterized and quantified by GC-MS analysis on an Agilent $6890 \mathrm{~N}$ gas chromatograph instrument equipped with an Agilent 5973 mass spectrometer and an HP-5MS capillary column (length $30 \mathrm{~m} \times 0.25 \mathrm{~mm}$ ID, film thickness $0.25 \mathrm{~mm}$; Agilent-Technologies, Palo Alto, CA, USA). The carrier gas was helium at a constant flow of $1.0 \mathrm{~mL} / \mathrm{min}$. The oven temperature programs were as follows: from $50{ }^{\circ} \mathrm{C}$ (held for $2 \mathrm{~min}$ ) to $80^{\circ} \mathrm{C}\left(2{ }^{\circ} \mathrm{C} / \mathrm{min}\right)$, from $80^{\circ} \mathrm{C}$ to $150{ }^{\circ} \mathrm{C}\left(5^{\circ} \mathrm{C} / \mathrm{min}\right)$, from $150{ }^{\circ} \mathrm{C}$ to $200^{\circ} \mathrm{C}\left(10^{\circ} \mathrm{C} / \mathrm{min}\right)$, from $200^{\circ} \mathrm{C}$ to $300^{\circ} \mathrm{C}\left(20^{\circ} \mathrm{C} / \mathrm{min}\right)$ and held there for $5 \mathrm{~min}$. The temperature of injector was $250^{\circ} \mathrm{C}$. The samples were diluted in hexane $(1: 40 \mathrm{v} / \mathrm{v})$, then $1 \mu \mathrm{L}$ of the diluted samples were injected in splitless mode. Component identification was done based on MS library search (NIST and Wiley). The percentage composition was calculated by integrating the peak areas of the chromatograms.

\subsection{Mosquito Rearing}

The colony of Aedes aegypti mosquitoes was reared in the insectary at the Faculty of Pharmacy, Lac Hong University using the standard procedures described by Manh et al. [15,16]. The insectary was kept at $27 \pm 3{ }^{\circ} \mathrm{C}, 70 \%-80 \%$ relative humidity with a photoperiod of $12 \mathrm{~h}$ light and $12 \mathrm{~h}$ dark. Larvae were placed in plastic trays and provided with cat food (Wiskcat), whereas adult mosquitoes were kept in breeding cages $(30 \mathrm{~cm} \times 30 \mathrm{~cm} \times 30 \mathrm{~cm})$ and maintained on a $10 \%$ sucrose solution. The female mosquitoes were fed with blood of live mice for mosquito reproduction. These studies were conducted following the Guide for the Care and Use of Laboratory Animals of Faculty of Pharmacy, Lac Hong University.

\subsection{Larvicidal Assay}

The larvicidal activity was tested based on the recommendations of WHO [17]. The essential oil was diluted in $1 \mathrm{ml}$ ethanol and then diluted in tap water to obtain $100 \mathrm{~mL}$ of serial solutions of different concentrations: 45, 60, 75, 90, 115, 120 part per million (ppm). Control solutions were made with $1 \mathrm{~mL}$ of alcohol in $99 \mathrm{~mL}$ of tap water. Batchs of 25 third or fourth instar larvae were transferred by pasteur pipette to cups containing a $100 \mathrm{~mL}$ test solution. Tests were replicated three times for each concentration. Food was not provided for the larvae during the test period. Dead larvae were counted after a $24 \mathrm{~h}$ exposure. 


\subsection{Repellent Test}

The repellent test was based on the WHO protocol (2009) [18] with a few modifications. The test was performed in a metal cage $(30 \mathrm{~cm} \times 20 \mathrm{~cm} \times 20 \mathrm{~cm})$ covered with a net. Fifty females (5-7 days old) were raised together with males to ensure copulation. They had no previous blood meal and had been fed on a sucrose solution of $10 \%$. These female mosquitoes starved for $12 \mathrm{~h}$ before the tests. Two mosquito cages were randomly assigned to each participant. One cage was used for testing the essential oil solution and the other for the positive control (20\% DEET standard solution in ethanol). The essential oil was tested at 25\%,50\%, 100\% concentration. In addition, a test solution containing the essential oil (25\%) and vanillin (5\%) was performed. Both forearms were covered with a rubber sleeve except a rectangle area $(3 \mathrm{~cm} \times 10 \mathrm{~cm})$, thus the skin within these rectangle areas were directly exposed to the mosquitoes. Before each test, the forearms were treated with negative control (only ethanol) in order to ensure host-seeking behavior. On the forearms, each rectangle area was treated with $0.1 \mathrm{~mL}$ of repellent (essential oil solution or DEET $20 \%$ solution). After that, the protection time was considered started and each treated forearm was then inserted into a different cage for $3 \mathrm{~min}$. If there was no mosquito bite, the test was repeated after a 30-minute interval. Once a mosquito sucked blood, the repellent test was considered finished. New mosquitoes were used for each test. Four volunteers who worked at the Faculty of Pharmacy and had no history of allergic reactions to mosquito bites were recruited. Following WHO's guideline [18], we selected equal numbers of female and male volunteers. To avoid the problem of the limited number of volunteers, each participant was tested twice on different days to confirm the results.

\subsection{Data Analysis}

Data analysis was performed by using the SPSS software program (IBM, version 22.0, Armonk, NY, USA). The larvicidal assay data were analyzed by probit analysis [19]. The probit-log(concentration) regression model was used to calculate $\mathrm{LC}_{50}$ values and $95 \%$ confidence limits. The differences in mean protection times among concentrations were analyzed by one-way ANOVA and Tukey's post-hoc test, $p<0.05$ was considered statistically significant.

\section{Results and Discussion}

\subsection{Yields and Chemical Constituents of the Essential Oil}

The essential oil obtained from the hydro-distillation of Mentha arvensis L. leaves was achieved after one-hour extraction. The yield of the essential oil was $0.67 \%(\mathrm{v} / \mathrm{w})$, calculated based on the fresh weight of the leaves. Table 1 shows the chemical composition of Mentha arvensis L. essential oil. The oxygenated monoterpenes (99.51\%) was the major terpenoid group, including the main components such as menthol (66.04\%), menthyl acetate $(22.19 \%)$, menthone $(2.51 \%)$, etc. Hydrocarbon monoterpenes $(2.86 \%)$ and sesquiterpenes $(0.90 \%)$ were the other terpenoid groups in lower proportion. There were thirteen main components in the essential oil in which menthol (66.04\%) was the most abundant. This result was in good agreement with previous studies where menthol was also the most abundant component in the essential oil extracted from Mentha arvensis L. grown in Cuba (51.68\%) [20], India (71.1\%) [21], and Pakistan ( 80\%) [22], etc. The essential oil of Mentha arvensis L., also known as corn mint oil, is the main source of natural menthol for food and pharmaceutical industries. 
Table 1. Chemical constituents (\%) of Mentha arvensis L. essential oil.

\begin{tabular}{ccccccc}
\hline No & RT (min) & Formula & Mass & Compound & Percentage (\%) & Terpenoid Group \\
\hline 1 & 7.4 & $\mathrm{C}_{10} \mathrm{H}_{16}$ & 136 & $\alpha$-Pinene & 0.34 & hydrocarbon monoterpenes \\
2 & 9.14 & $\mathrm{C}_{10} \mathrm{H}_{16}$ & 136 & Sabinene & 0.09 & hydrocarbon monoterpenes \\
3 & 9.23 & $\mathrm{C}_{10} \mathrm{H}_{16}$ & 136 & $\beta$-Pinene & 0.39 & hydrocarbon monoterpenes \\
4 & 11.93 & $\mathrm{C}_{10} \mathrm{H}_{16}$ & 136 & Limonene & 2.04 & hydrocarbon monoterpenes \\
5 & 19.22 & $\mathrm{C}_{10} \mathrm{H}_{18} \mathrm{O}$ & 154 & Menthone & 2.51 & 1.45 \\
6 & 19.73 & $\mathrm{C}_{10} \mathrm{H}_{18} \mathrm{O}$ & 154 & Isomenthone & 1.89 & oxygenated monoterpenes \\
7 & 19.83 & $\mathrm{C}_{10} \mathrm{H}_{20} \mathrm{O}$ & 156 & neo-Menthol & 66.04 & oxygenated monoterpenes \\
8 & 20.48 & $\mathrm{C}_{10} \mathrm{H}_{20} \mathrm{O}$ & 156 & Menthol & 0.2 & oxygenated monoterpenes \\
9 & 20.75 & $\mathrm{C}_{10} \mathrm{H}_{20} \mathrm{O}$ & 156 & Isomenthol & 1.47 & oxygenated monoterpenes \\
10 & 23.69 & $\mathrm{C}_{10} \mathrm{H}_{16} \mathrm{O}$ & 152 & Piperitone & 22.19 & oxygenated monoterpenes \\
11 & 25.26 & $\mathrm{C}_{10} \mathrm{H}_{22} \mathrm{O} 2$ & 204 & Menthyl acetate & 0.59 & hydrocarbon sesquiterpenes \\
12 & 29.15 & $\mathrm{C}_{15} \mathrm{H}_{24}$ & 204 & Caryophyllene & 0.31 & oxygenated sesquiterpenes \\
13 & 33.32 & $\mathrm{C}_{15} \mathrm{H}_{24} \mathrm{O}$ & 220 & Caryophyllene oxide &
\end{tabular}

\subsection{Larvicidal Activity}

Table 2 shows the toxicity of the essential oil against Aedes aegypti larvae. No mortality was seen in the control, while all larvae died at a concentration of $120 \mathrm{ppm}$. The $\mathrm{LC}_{50}$ and $\mathrm{LC}_{90}$ were 78.1 and 125.7 ppm, respectively.

Table 2. Larvicidal activity of Mentha arvensis L. essential oil against Aedes aegypti larvae after 24 h exposure.

\begin{tabular}{|c|c|c|c|c|c|}
\hline $\begin{array}{c}\text { Concentration } \\
(\mathrm{ppm})\end{array}$ & $\begin{array}{l}\text { Mortality } \\
(\%) \pm \text { SD }\end{array}$ & Slope $( \pm$ SE) & $\begin{array}{l}\mathrm{LC}_{50} \mathrm{ppm} \\
\text { (CL 95\%) }\end{array}$ & $\begin{array}{l}\mathrm{LC}_{90} \mathrm{ppm} \\
\text { (CL 95\%) }\end{array}$ & $x^{2}(\mathrm{df})$ \\
\hline 0 (control) & 0 & & & & \\
\hline 45 & $10.7 \pm 4.6$ & & & & \\
\hline 60 & $18.7 \pm 4.6$ & 6.201 & 78.1 & 125.7 & 24.9 \\
\hline 75 & $45.3 \pm 20.5$ & $( \pm 0.630)$ & $(72.0-85.4)$ & (109.4-160.5) & (13) \\
\hline 90 & $58.7 \pm 16.7$ & & & & \\
\hline 105 & $85.3 \pm 8.3$ & & & & \\
\hline 120 & 100 & & & & \\
\hline
\end{tabular}

$\mathrm{SD}=$ Standard deviation, $\mathrm{LC}_{50}=$ lethal concentration that kills $50 \%$ of larvae, $\mathrm{LC}_{90}=$ lethal concentration that kills $90 \%$ of larvae, $\mathrm{CL}=$ confidence limits at $95 \%, \mathrm{SE}=$ standard errors, $\chi 2=$ chi-square value, and $\mathrm{df}=\mathrm{degrees}$ of freedom.

In a recent review, Pavela [23] has found that most essential oils with the value of $\mathrm{LC}_{50}$ less than 100 ppm against mosquito larvae were from five botanical families: Myrtaceae, Apiaceae, Rutaceae, Cupressaceae, and Lamiaceae. The genus Mentha, which belongs to Lamiaceae family, is cultivated over the world, and their oils have shown larvicidal effects on Aedes aegypti larvae [24-26]. However, the studies on the larvicidal effect of Mentha genus against Aedes aegypti larvae was limited to Mentha piperita [24], Mentha $x$ villosa [25], and Mentha spicata [26]. In these previous studies, the $\mathrm{LC}_{50}$ value of Mentha piperita oil was $98.7 \mathrm{ppm}$ [24], while the Mentha spicata oil and Mentha $x$ villosa oil showed lower $\mathrm{LC}_{50}$ values of $56.1 \mathrm{ppm}, 45.0 \mathrm{ppm}$, respectively. In this study, the $\mathrm{LC}_{50}$ value of Mentha arvensis essential oil was $78.1 \mathrm{ppm}$. In comparison with the essential oils, the synthetic chemical Temephos had a much lower $\mathrm{LC}_{50}$ value of $0.043 \mathrm{ppm}$ [25]. Although Mentha arvensis L. essential oil shows the larvicidal effect against Aedes aegypti, further investigations on field application are neccessary.

Regarding the mode of action, essential oils can produce neurotoxic effects on insects through several targets such as inhibiting acetylcholinesterase enzyme in the cholinergic system [27] or acting on Octopamine receptor [28,29] and GABA receptor [30]. Furthermore, the synergistic effects of essential oil components probably increase the toxicity of the essential oil. Hummelbrunner et al. [31] found that thymol acted synergistically with trans-anethole to enhance the acute toxicity to tobacco cutworms. Osanlo et al. [32] found that the clove oil was more toxic than its major component eugenol. They 
suggested that the minor compound might act as a synergist that enhance the toxicity of the major compound. Santos et al. [33] reported that menthol had an $\mathrm{LC}_{50}$ value of 404 ppm against Aedes aegypti larvae. This value was much higher than $\mathrm{LC}_{50}$ value of $78.1 \mathrm{ppm}$ of the Mentha arvensis essential oil, which contained menthol as the major component in this study.

\subsection{Repellent Activity}

Figure 1 shows the repellency of the essential oil at different concentrations in ethanol compared with DEET 20\%. The repellency of the essential oil increased with the concentration. The mean complete protection times were 45,90 , and $165 \mathrm{~min}$ at the concentration of $25 \%, 50 \%$, and $100 \%$, respectively. When adding $5 \%$ vanillin to the essential oil $(25 \%)$, the complete protection time of the oil increased up to $120 \mathrm{~min}$. However, the essential oil had a short protection time compared with Deet 20\% (360 min). Campbell et al. [34] found that forty-two compounds in eleven essential oils elicited antennal responses from Aedes aegypti. These compounds were also found in the Mentha arvensis essential oil such as menthol, menthyl acetate, menthone, caryophyllene, and $\beta$-pinene.

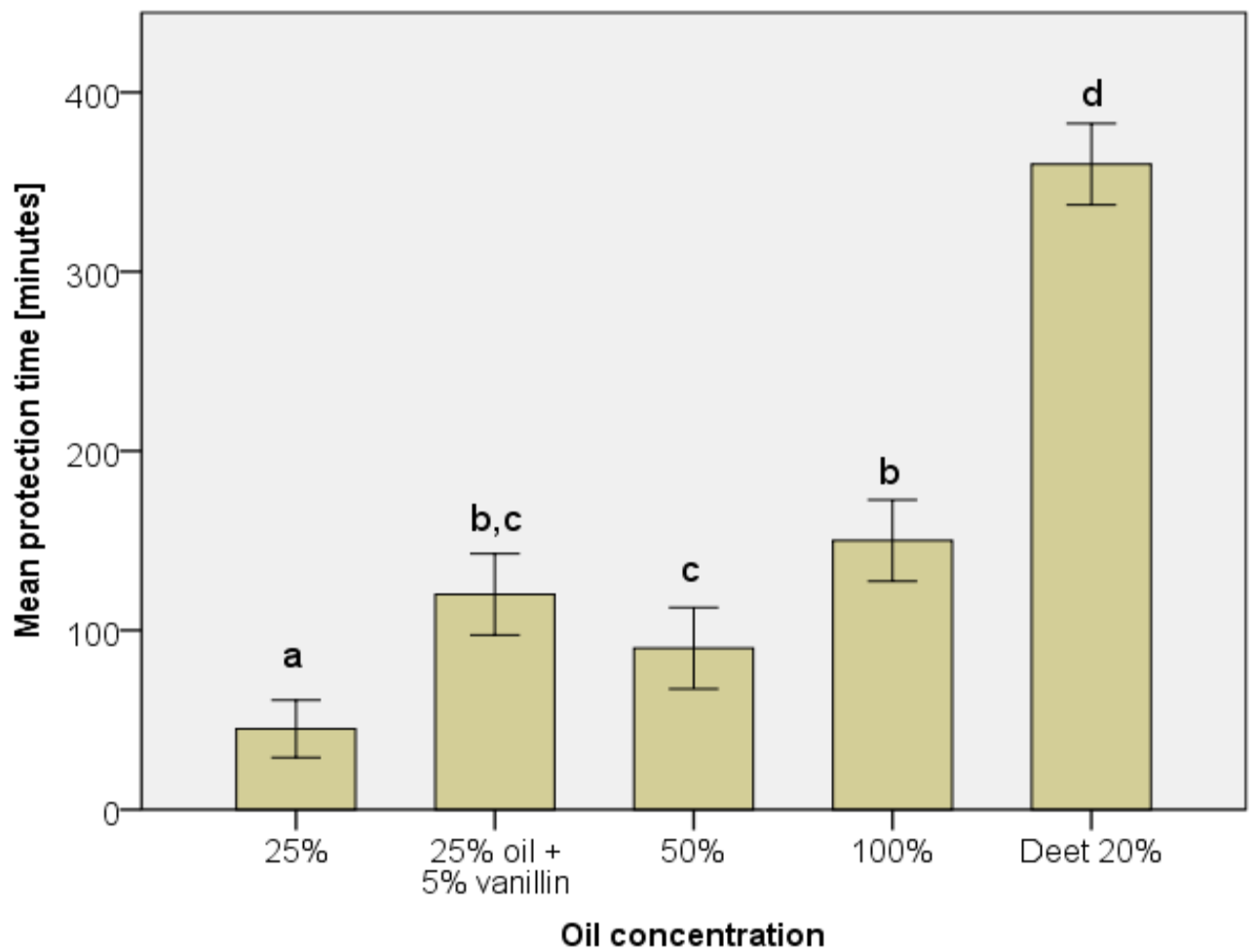

Figure 1. Protection times of Mentha arvensis L. essential oil against Aedes aegypti mosquitoes. Data are shown as mean $\pm \operatorname{SD}(n=4)$. Letters are used to show statistical significance $(p<0.05)$. Bars are significantly different if they do not share letters.

The use of essential oils such as citronella oil, lemongrass oil, and eucalyptus oil is widely accepted as mosquito repellents [11]. Mosquitoes locate the human host by integrating olfactory, thermal, and visual cues. Among these, odors play an important role in human host detection [35]. Mosquitoes detect human odors such as $\mathrm{CO}_{2}$, acid lactic, and 1-octen-3-ol when that volatile odors bind to their odor receptors. The mode of action of mosquito repellents remains a controversial topic in which they may activate receptors associated with repellency or inhibit receptors associated with attraction [36].

Essential oils might produce effects through interaction with odor receptors, therefore decreases contacts between mosquitoes and their hosts. However, due to their high volatility, most essential oils have short repellent action, as compared with synthetic DEET [37]. To solve this problem, Khan et al. [38] used vanillin as a fixative to increase their protection time. Table 3 shows a review of the previous 
studies that reported the protection time of essential oils with and without vanillin. Tawasin et al. [39] found that an addition of $5 \%$ vanillin to citronella oil could significantly increase the protection time against Aedes aegypti up to $6.5 \mathrm{~h}$. Songkro et al. [40] compared the evaporation rate of the citronella oil with and without vanillin. They found that citronella oil with vanillin had a lower rate of evaporation. Adding vanillin to Zanthoxylum piperitum [41], Curcuma longa, Eucalyptus globulus, Citrus aurantium [42], and lemongrass oil [43], etc was also reported to increase their protection times. However, if only $5 \%$ vanillin solution was tested, the protection time was $15 \mathrm{~min}$ [43]. Therefore, vanillin has acted as a synergist to those essential oils to enhance their repellency. In the present study, we found that the addition of $5 \%$ vanillin to the Mentha arvensis essential oil ( $25 \%)$ increased the protection time of the oil nearly 3 times, from $45 \mathrm{~min}$ up to $120 \mathrm{~min}$. Recently, nanotechnology has been applied to slow the release rate of essential oil and thus prolong the protection time. Sakulku et al. [44] developed citronella oil nanoemulsion and found that the release rate of the essential oil in the nanoemulsion decreased and thus its protection time increased. Nuchuchua et al. [45] developed a nanoemulsion containing citronella oil, hairy basil oil, and vetiver oil. They found that this nanoemulsion increased the protection time up to $4.7 \mathrm{~h}$. Although EO of Mentha arvensis L. shows promising repellency, incorporating the $\mathrm{EO}$ and vanillin into a nanoemulsion might extend their mosquito protection time.

Table 3. A review of protection times of essential oils with or without vanillin, against Aedes aegypti mosquitoes.

\begin{tabular}{|c|c|c|c|c|c|c|}
\hline Essential Oils & Volume/Oil Concentration & $\begin{array}{c}\text { Vanillin } \\
\text { Concentration }\end{array}$ & Test Method & Area/Part Treated & $\begin{array}{c}\text { Protection Time } \\
\text { (Without-With } \\
\text { Vanillin) }\end{array}$ & Ref. \\
\hline Mentha arvensis & $0.1 \mathrm{~mL}$ of $25 \%$ in ethanol & $5 \%$ & Arm-in- Cage & $30 \mathrm{~cm}^{2} /$ forearm & $45-120$ (min) & This study \\
\hline Tumeric & $0.1 \mathrm{~mL}$ of $25 \%$ in ethanol & $5 \%$ & Arm-in- Cage & $30 \mathrm{~cm}^{2} /$ forearm & $1.0-4.0(\mathrm{~h})$ & [39] \\
\hline Kaffir lime & $0.1 \mathrm{~mL}$ of $25 \%$ in ethanol & $5 \%$ & Arm-in- Cage & $30 \mathrm{~cm}^{2} /$ forearm & $1.0-3.5(\mathrm{~h})$ & [39] \\
\hline Citronella & $0.1 \mathrm{~mL}$ of $25 \%$ in ethanol & $5 \%$ & Arm-in- Cage & $30 \mathrm{~cm}^{2} /$ forearm & $3.0-6.5(\mathrm{~h})$ & [39] \\
\hline Hairy basil & $0.1 \mathrm{~mL}$ of $25 \%$ in ethanol & $5 \%$ & Arm-in- Cage & $30 \mathrm{~cm}^{2} /$ forearm & $3.0-6.5(\mathrm{~h})$ & [39] \\
\hline Zanthoxylum piperitum & $0.1 \mathrm{~mL}$ of pure oil & $10 \%$ & Arm-in- Cage & $30 \mathrm{~cm}^{2} /$ forearm & $1.0-2.5(\mathrm{~h})$ & [41] \\
\hline Curcuma longa & $0.1 \mathrm{~mL}$ of $25 \%$ in coconut oil & $5 \%$ & Arm-in- Cage & $30 \mathrm{~cm}^{2} /$ forearm & $1.5-2.5(h)$ & [42] \\
\hline Eucalyptus globulus & $0.1 \mathrm{~mL}$ of $25 \%$ in coconut oil & $5 \%$ & Arm-in- Cage & $30 \mathrm{~cm}^{2} /$ forearm & $66-144$ (min) & [42] \\
\hline Citrus aurantium & $0.1 \mathrm{~mL}$ of $25 \%$ in coconut oil & $5 \%$ & Arm-in- Cage & $30 \mathrm{~cm}^{2} /$ forearm & $66-120(\mathrm{~min})$ & [42] \\
\hline Cassia oil & $0.1 \mathrm{~mL}$ of $5 \%$ in ethanol & $5 \%$ & Arm-in- Cage & $24 \mathrm{~cm}^{2} /$ forearm & 75-135 (min) & [43] \\
\hline Rosemary & $0.1 \mathrm{~mL}$ of $5 \%$ in ethanol & $5 \%$ & Arm-in- Cage & $24 \mathrm{~cm}^{2} /$ forearm & $0-52(\min )$ & [43] \\
\hline Lemon eucalyptus & $0.1 \mathrm{~mL}$ of $5 \%$ in ethanol & $5 \%$ & Arm-in- Cage & $24 \mathrm{~cm}^{2} /$ forearm & $22.5-60.0(\mathrm{~min})$ & [43] \\
\hline Xanthoxylum & $0.1 \mathrm{~mL}$ of $5 \%$ in ethanol & $5 \%$ & Arm-in- Cage & $24 \mathrm{~cm}^{2} /$ forearm & $30-60(\mathrm{~min})$ & [43] \\
\hline Lemongrass & $0.1 \mathrm{~mL}$ of $5 \%$ in ethanol & $5 \%$ & Arm-in- Cage & $24 \mathrm{~cm}^{2} /$ forearm & 30-105 (min) & [43] \\
\hline
\end{tabular}

\section{Conclusions}

Our findings suggest that Mentha arvensis L. essential oil exhibits toxicity to the larvae of Aedes aegypti, which may be considered as a potential larvicide for controlling mosquito population. In addition, the EO shows excellent repellency against Aedes aegypti mosquitoes when adding 5\% vanillin. Further studies on field applications as well as new repellent formulations based on the essential oil are necessary.

Author Contributions: Conceptualization, H.D.M.; methodology, H.D.M.; software, O.T.T.; validation, O.T.T. and H.D.M.; formal analysis, O.T.T.; investigation, and H.D.M.; resources, H.D.M.; data curation, O.T.T.; writing —original draft preparation, O.T.T; writing—review and editing, H.D.M; visualization, O.T.T.; supervision, H.D.M.; project administration, H.D.M.; funding acquisition, O.T.T. All authors have read and agree to the published version of the manuscript.

Funding: This research was funded by Lac Hong University, grant number LHU-RF-MP-18-01-12.

Acknowledgments: The authors are very much grateful to Nguyen Thi Thanh Thuy, Institute of Applied Materials Science at Ho Chi Minh city for their valuable help in GC-MS analysis of the essential oils.

Conflicts of Interest: The authors declare no conflict of interest. 


\section{References}

1. Guzman, M.G.; Halstead, S.B.; Artsob, H.; Buchy, P.; Farrar, J.J.; Gubler, D.J.; Hunsperger, E.; Kroeger, A.; Margolis, H.S.; Martinez, E.; et al. Dengue: A continuing global threat. Nat. Rev. Genet. 2010, 8, S7-S16. [CrossRef] [PubMed]

2. Simmons, C.P.; Farrar, J.J.; Chau, N.V.V.; Wills, B. Dengue. New Engl. J. Med. 2012, 366, 1423-1432. [CrossRef] [PubMed]

3. Khasnis, A.A.; Nettleman, M.D. Global Warming and Infectious Disease. Arch. Med. Res. 2005, 36, 689-696. [CrossRef] [PubMed]

4. Zaim, M.; Guillet, P. Alternative insecticides: An urgent need. Trends Parasitol. 2002, 18, 161-163. [CrossRef]

5. Norris, E.J.; Coats, J.R. Current and Future Repellent Technologies: The Potential of Spatial Repellents and Their Place in Mosquito-Borne Disease Control. Int. J. Environ. Res. Public Health 2017, 14, 124. [CrossRef] [PubMed]

6. Kawada, H.; Higa, Y.; Nguyen, Y.T.; Tran, S.H.; Nguyen, H.T.; Takagi, M. Nationwide Investigation of the Pyrethroid Susceptibility of Mosquito Larvae Collected from Used Tires in Vietnam. PLOS Negl. Trop. Dis. 2009, 3, e391. [CrossRef] [PubMed]

7. Koureas, M.; Tsakalof, A.; Tsatsakis, A.; Hadjichristodoulou, C. Systematic review of biomonitoring studies to determine the association between exposure to organophosphorus and pyrethroid insecticides and human health outcomes. Toxicol. Lett. 2012, 210, 155-168. [CrossRef]

8. Roy, D.N.; Goswami, R.; Pal, A. The insect repellents: A silent environmental chemical toxicant to the health. Environ. Toxicol. Pharmacol. 2017, 50, 91-102. [CrossRef]

9. Menon, K.S.; Brown, A.E. Exposure of children to deet and other topically applied insect repellents. Am. J. Ind. Med. 2004, 47, 91-97. [CrossRef]

10. Goodyer, L.; Behrens, R.H. Short report: The safety and toxicity of insect repellents. Am. J. Trop. Med. Hyg. 1998, 59, 323-324. [CrossRef]

11. Maia, M.F.; Moore, S.J. Plant-based insect repellents: A review of their efficacy, development and testing. Malar. J. 2011, 10, S11. [CrossRef] [PubMed]

12. Rehman, J.; Ali, A.; Khan, I.A. Plant based products: Use and development as repellents against mosquitoes: A review. Fitoter 2014, 95, 65-74. [CrossRef] [PubMed]

13. Nerio, L.S.; Olivero-Verbel, J.; Stashenko, E. Repellent activity of essential oils: A review. Bioresour. Technol. 2010, 101, 372-378. [CrossRef] [PubMed]

14. Carroll, S.P.; Loye, J. PMD, a registered botanical mosquito repellent with deet-like efficacy. J. Am. Mosq. Control Assoc. 2006, 22, 507-514. [CrossRef]

15. Manh, H.D.; Huong, D.N.X.; Hanh, L.T.H.; Duong, N.T.T. Rearing of Aedes aegypti Mosquitoes in the laboratory and assessing the larvicide of lemongrass oil (Cymbopogon citratus) and lemon eucalyptus oil (Corymbia citriodora) against Aedes aegypti larvae. J. Sci. Lac Hong Univ. 2019, 7, 057-061.

16. Manh, H.D.; Hue, D.T.; Hieu, N.T.T.; Tuyen, D.T.T.; Tuyet, O.T.; Manh, H.D. The Mosquito Larvicidal Activity of Essential Oils from Cymbopogon and Eucalyptus Species in Vietnam. Insects 2020, 11, 128. [CrossRef]

17. World Health Organization. Guidelines for Laboratory and Field Testing of Mosquito Larvicides; World Health Organization: Geneva, Switzerland, 2005; pp. 1-41. Available online: https://apps.who.int/iris/handle/10665/ 69101 (accessed on 12 May 2018).

18. World Health Organization. Guidelines for Efficacy Testing of Mosquito Repellents for Human Skin; World Health Organization: Geneva, Switzerland, 2009; pp. 1-6. Available online: https:/apps.who.int/iris/handle/10665/ 70072 (accessed on 12 May 2018).

19. Fitney, D.J. Probit Analysis, 3rd ed.; Cambridge University Press: London, UK, 1971.

20. Pino, J.A.; Rosado, A.; Fuentes, V. Chemical Composition of the Essential Oil of Mentha arvensis L. var. piperascens Malinv from Cuba. J. Essent. Oil Res. 1996, 8, 685-686. [CrossRef]

21. Hussain, A.I.; Anwar, F.; Nigam, P.S.; Ashraf, M.; Gilani, A. Seasonal variation in content, chemical composition and antimicrobial and cytotoxic activities of essential oils from four Mentha species. J. Sci. Food Agric. 2010, 90, 1827-1836. [CrossRef]

22. Rao, B.R.R.; Kaul, P.N.; Mallavarapu, G.R.; Ramesh, S. Comparative Composition of Whole Herb, Flowers, Leaves and Stem Oils of Cornmint (Mentha arvensis L.f. piperascens Malinvaud ex Holmes). J. Essent. Oil Res. 2000, 12, 357-359. 
23. Pavela, R. Essential oils for the development of eco-friendly mosquito larvicides: A review. Ind. Crop. Prod. 2015, 76, 174-187. [CrossRef]

24. Kumar, S.; Wahab, N.; Warikoo, R. Bioefficacy of Mentha piperita essential oil against dengue fever mosquito Aedes aegypti L. Asian Pac. J. Trop. Biomed. 2011, 1, 85-88. [CrossRef]

25. Lima, T.C.; Da Silva, T.K.M.; Silva, F.; Barbosa-Filho, J.M.; Marques, M.O.M.; Santos, R.L.C.; Cavalcanti, S.C.D.H.; De Sousa, D.P. Larvicidal activity of Mentha x villosa Hudson essential oil, rotundifolone and derivatives. Chemosphere 2014, 104, 37-43. [CrossRef] [PubMed]

26. Govindarajan, M.; Sivakumar, R.; Rajeswari, M.; Yogalakshmi, K. Chemical composition and larvicidal activity of essential oil from Mentha spicata (Linn.) against three mosquito species. Parasitol. Res. 2011, 110, 2023-2032. [CrossRef] [PubMed]

27. Houghton, P.J.; Ren, Y.; Howes, M.-J. Acetylcholinesterase inhibitors from plants and fungi. Nat. Prod. Rep. 2006, 23, 181. [CrossRef] [PubMed]

28. Enan, E. Insecticidal activity of essential oils: Octopaminergic sites of action. Comp. Biochem. Physiol. Part C: Toxicol. Pharmacol. 2001, 130, 325-337. [CrossRef]

29. Kostyukovsky, M.; Rafaeli, A.; Gileadi, C.; Demchenko, N.; Shaaya, E. Activation of octopaminergic receptors by essential oil constituents isolated from aromatic plants: Possible mode of action against insect pests. Pest Manag. Sci. 2002, 58, 1101-1106. [CrossRef]

30. Priestley, C.M.; Williamson, E.; A Wafford, K.; Sattelle, D.B. Thymol, a constituent of thyme essential oil, is a positive allosteric modulator of human GABAA receptors and a homo-oligomeric GABA receptor from Drosophila melanogaster. Br. J. Pharmacol. 2003, 140, 1363-1372. [CrossRef]

31. Hummelbrunner, L.A.; Isman, M. Acute, sublethal, antifeedant, and synergistic effects of monoterpenoid essential oil compounds on the tobacco cutworm, Spodoptera litura (Lep., Noctuidae). J. Agric. Food Chem. 2001, 49, 715-720. [CrossRef]

32. Osanloo, M.; Sedaghat, M.M.; Esmaeili, F.; Amani, A. Larvicidal Activity of Essential Oil of Syzygium aromaticum (Clove) in Comparison with Its Major Constituent, Eugenol, against Anopheles stephensi. J. Arthropod-Borne Dis. 2018, 12, 361-369.

33. Santos, S.R.; Melo, M.A.; Cardoso, A.V.; Santos, R.L.; De Sousa, D.P.; Cavalcanti, S.C.H. Structure-activity relationships of larvicidal monoterpenes and derivatives against Aedes aegypti Linn. Chemosphere 2011, 84, 150-153. [CrossRef]

34. Campbell, C.; Gries, R.; Gries, G. Forty-two compounds in eleven essential oils elicit antennal responses from Aedes aegypti. Èntomol. Exp. Appl. 2010, 138, 21-32. [CrossRef]

35. Raji, J.; DeGennaro, M. Genetic Analysis of Mosquito Detection of Humans. Curr. Opin. Insect Sci. 2017, 20, 34-38. [CrossRef] [PubMed]

36. Dickens, J.C.; Bohbot, J. Mini review: Mode of action of mosquito repellents. Pestic. Biochem. Physiol. 2013, 106, 149-155. [CrossRef]

37. Barnard, D.R. Repellency of essential oils to mosquitoes (Diptera: Culicidae). J. Med. Èntomol. 1999, 36, 625-629. [CrossRef] [PubMed]

38. Khan, A.; Maibach, H.I.; Skidmore, D.L. Addition of Vanillin to Mosquito Repellents to Increase Protection Time. Mosq. News 1975, 35, 223-225.

39. Tawatsin, A.; Wratten, S.D.; Scott, R.R.; Thavara, U.; Techadamrongsin, Y. Repellency of volatile oils from plants against three mosquito vectors. J. Vector Ecol. 2001, 26, 76-82.

40. Songkro, S.; Jenboonlap, M.; Boonprasertpon, M.; Maneenuan, D.; Bouking, K.; Kaewnopparat, N. Effects of glucam P-20, vanillin, and fixolide on mosquito repellency of citronella oil lotions. J. Med. Èntomol. 2012, 49, 672-677. [CrossRef]

41. Choochote, W.; Chaithong, U.; Kamsuk, K.; Jitpakdi, A.; Tippawangkosol, P.; Tuetun, B.; Champakaew, D.; Pitasawat, B. Repellent activity of selected essential oils against. Fitoter 2007, 78, 359-364. [CrossRef]

42. Auysawasdi, N.; Chuntranuluck, S.; Phasomkusolsil, S.; Keeratinijakal, V. Improving the effectiveness of three essential oils against (Linn.) and Anopheles dirus (Peyton and Harrison). Parasitol. Res. 2015, 115, 99-106. [CrossRef]

43. Kim, S.-I.; Yoon, J.-S.; Baeck, S.-J.; Lee, S.-H.; Ahn, Y.-J.; Kwon, H.W. Toxicity and synergic repellency of plant essential oil mixtures with vanillin against (Diptera: Culicidae). J. Med. Èntomol. 2012, 49, 876-885. [CrossRef] 
44. Sakulku, U.; Nuchuchua, O.; Uawongyart, N.; Puttipipatkhachorn, S.; Soottitantawat, A.; Ruktanonchai, U.R. Characterization and mosquito repellent activity of citronella oil nanoemulsion. Int. J. Pharm. 2009, 372, 105-111. [CrossRef] [PubMed]

45. Nuchuchua, O.; Sakulku, U.; Uawongyart, N.; Puttipipatkhachorn, S.; Soottitantawat, A.; Ruktanonchai, U.R. In Vitro Characterization and Mosquito () Repellent Activity of Essential-Oils-Loaded Nanoemulsions. AAPS PharmSciTech 2009, 10, 1234-1242. [CrossRef] [PubMed]

C 2020 by the authors. Licensee MDPI, Basel, Switzerland. This article is an open access article distributed under the terms and conditions of the Creative Commons Attribution (CC BY) license (http://creativecommons.org/licenses/by/4.0/). 